\title{
ЕФЕКТИВНІСТЬ СПОСОБІВ УТЕПЛЕННЯ ЦОКОЛЬНИХ ТА ПІДВАЛЬНИХ ПРИМІЩЕНЬ
}

\section{EFFICIENCY OF THE METHODS OF INSULATION OF BASEMENTS}

Пахолюк О.А. к.т.н., доц., Чапюк О.С. к.т.н., доц. (Луцький національний технічний університет, м. Луцьк)

Pakholiuk O., Ph.D. in Engineering, Associate Professor, Chapiuk O., Ph.D. in Engineering, Associate Professor (Lutsk National Technical University, Lutsk).

У статті описано методи утеплення цокольних та підвальних приміщень, які застосовуються в сучасній практиці будівництва, проведено визначення і порівняння їх ефективності, визначено межі застосування таких методів.

Due to the low energy efficiency of buildings, heat loss buildings make up $47 \%, 12 \%$ of heat is lost due to worn-out networks, and $5 \%$ due to outdated boiler installations. With the help of heat modernization and overhaul in homes, you can reduce annual consumption and energy losses by $10-25 \%$.

At the same time, in Ukraine as a whole, the potential for reducing energy consumption is $75 \%$.

The main consumption of energy in the residential sector is connected with the heating of the house due to heat losses through windows, walls, roof, floor and due to ventilation. To save on resource costs and reduce heat losses, energy savings should be attributed to consumers, in systems of heat supply, heating, ventilation and air conditioning. The solution to these measures is related to the thermomodernization of buildings through insulation of exterior walls, attics, roofs, etc., as well as replacement for more energy efficient windows and doors; increase of useful energy use due to the use of recuperators, thermoregulators, heat pumps and other new energy-saving technologies. The introduction of measures for thermo-modernization will help to increase the service life of the residential sector buildings. 
Previous studies have shown that even during the thermomodernization of buildings, the issue of insulation of the walls of basement or basement premises often neglects or reduce the required thickness of the heater.

The classic layout of the wall insulation of the basement involves a significant amount of excavation work related to soil extraction, backfill, and reclamation. Performing such works to the required depth is not always technically feasible and is always materially costly. The same operations during the construction of a new building are introduced into the general cycle and increase the duration only for the immediate implementation of the insulation of the insulation, waterproofing and mechanical protection of the heater.

To cheapen the work, and sometimes the only technically feasible option is the insulation of the wall is not at full depth with the insert of the heater under paving. Let's check also the variant which unites the two previous ones.

Ключові слова: енергоефективність будівель, термомодернізація, методи утеплення.

Keywords: energy efficiency of buildings, thermo-modernization, methods of insulation.

На думку експертів Європейсько-українського енергетичного агентства, за допомогою термомодернізації та капітального ремонту в будинках можна зменшити щорічне споживання і втрати енергії на 10-25\%. При цьому в цілому по Україні потенціал зменшення енергоспоживання становить $75 \%$ [2].

3 огляду на дані, основне споживання енергоносіїв в житловому секторі пов'язане 3 опаленням будинку 3 причини теплових втрат через вікна, стіни, дах, підлогу та за рахунок вентиляції. До економії витрат ресурсів і зниження тепловтрат, у першу чергу слід віднести енергозбереження у споживачів, в системах теплопостачання, опалення, вентиляції і кондиціювання повітря. Вирішення цих заходів пов'язане 3 проведенням термомодернізації будинків через утеплення зовнішніх стін, горищ, дахів тощо, а також заміну на більш енергоефективні вікон і дверей; збільшення корисного використання енергії за рахунок застосування рекуператорів, терморегуляторів, теплових насосів та інших новітніх енергозберігаючих технологій. Впровадження 
заходів 3 термомодернізації буде сприяти збільшенню строку служби будівель житлового сектору області [1].

Згідно 3 [3] термомодернізація будівель - це комплекс робіт, спрямованих як на підвищення теплотехнічних показників огороджувальних конструкцій будівель (утеплення стін, заміна вікон), так i показників споживання енергетичних ресурсів інженерними системами та отже забезпечення енергетичної ефективності будівель в цілому. Лише такий комплексний підхід дозволить зменшити енергоспоживання будинку, що підтверджується результатами, які отримані в [4], де відзначено, що навіть ті будинки, які були утеплені, особливо не відрізняються за рівнем енергоспоживання від тих, які є неутепленими.

Згідно 3 вимогами ДБН В.2.6-31:2016 «Теплова ізоляція будівель», норми якого встановлюють вимоги до показників енергоефективності та теплотехнічних показників огороджувальних конструкцій (теплоізоляційної оболонки) будівель і споруд під час їх проектування та будівництва i порядку їх оцінювання 3 метою забезпечення раціонального використання ресурсів на опалення, охолодження та гаряче водопостачання, забезпечення санітарногігієнічних параметрів мікроклімату приміщень, довговічності огороджувальних конструкцій під час експлуатації будівель; застосовують при проектуванні будівель, що опалюються, кондиціонуються та охолоджуються, при новому будівництві, реконструкції, капітальному ремонті, термомодернізації при складанні енергетичного паспорта та оцінюванні енергетичних показників при визначенні витрат паливно-енергетичних ресурсів для опалення, охолодження, вентиляції, гарячого водопостачання та освітлення будівель

- При проектуванні теплоізоляційної оболонки будівлі на основі багатошарових конструкцій необхідно розташовувати з внутрішньої сторони конструкцій шари 3 матеріалів, що мають більш високу теплопровідність, теплоємність та опір паропроникненню;

- Шари 3 теплоізоляційних матеріалів слід розташовувати 3 зовнішньої сторони несучої частини стін;

- Огороджувальні конструкції, що контактують 3 грунтом, необхідно захищати від грунтової вологи горизонтальної гідроізоляції, а в підземній частині - вертикальної гідроізоляції. 
Згідно 3 п. 4.10 ДСТУ Б В.2.6-189:2013 «Методи вибору теплоізоляційного матеріалу для утеплення будівель» зовнішні заглиблені стінові конструкції, що контактують 3 грунтом, у будівлях без підвалу необхідно утеплювати теплоізоляційними матеріалами на глибину 0,5 м нижче поверхні грунту, у будівлях 3 підвалом - на глибину 1,0 м нижче поверхні грунту. Товщину теплоізоляційного матеріалу визначають за умови забезпечення вимоги (6) ДБН В.2.6-31 для огороджувальних конструкцій опалюваних приміщень, але не менше ніж 50 мм.

$$
\mathrm{T}_{\mathrm{B}_{\min }}>\mathrm{T}_{\min }
$$

де $\mathrm{T}_{\min }$ - мінімальне значення температури внутрішньої поверхні в зонах теплопровідних включень в огороджувальній конструкції, ${ }^{0} \mathrm{C}$;

$\mathrm{T}_{\min }-$ мінімально допустиме значення температури внутрішньої поверхні при розрахункових значеннях температур внутрішнього й зовнішнього повітря, ${ }^{0} \mathrm{C}$.

Мінімально допустиме значення температури внутрішньої поверхні непрозорих огороджувальних конструкцій у зонах теплопровідних включень повинно бути не менше, ніж температура точки роси Тр за розрахунковими значеннями температури й відносної вологості внутрішнього повітря, які приймаються залежно від призначення будівлі.

Попередні дослідження показали, що навіть при проведенні термомодернізації будівель питанням утеплення стін цокольних чи підвальних приміщень часто нехтують або зменшують необхідну товщину утеплювача.

Класична схема утеплення стіни підвалу передбачає значний обсяг земляних робіт, пов'язаних із вийманням грунту, зворотною засипкою і рекультивацією. Виконання таких робіт на необхідну глибину не завжди є технічно можливим і завжди є матеріально затратним. Ті ж операції при зведенні нової будівлі введені в загальний цикл і збільшують тривалість лише на виконання безпосередньо кріплення утеплювача, гідроізоляції та механічного захисту утеплювача.

Для здешевлення робіт, а часом єдино технічно можливим варіантом є утеплення стіни не на повну глибину із вкладанням утеплювача під мощення. Перевіримо також варіант, який об'єднує два попередніх.

Задачею дослідження буде порівняти ефективність таких систем утеплення. 
Для порівняння буде також виконано моделювання неутеплених конструкцій.

\section{Методика експерименту}

Для моделювання вибрана класична стіна 3 повнотілої керамічної цегли товщиною 510 мм із внутрішньою штукатуркою складним розчином (пісок, вапно, цемент) товщиною 20 мм. Залізобетонна порожниста плита перекриття обпирається на фундамент з бетонних блоків. Низ плити знаходиться на відмітці 0.320 , рівень грунту - на відмітці -0.720 .

Стіна утеплена базальтоволокнистою плитою товщиною 150 мм і покрита захисним та оздоблювальним шаром.

Фундамент утеплений екструдованим пінополістиролом мінімально допустимої товщини 50 мм, який також покритий захисним та оздоблювальним шаром.

У розрахунковій моделі застосовані певні спрощення конструкції.

Розрахункова температура зовнішнього середовища $-22^{\circ} \mathrm{C}$, всередині приміщення $+20^{\circ} \mathrm{C}$, у підвалі $+10^{\circ} \mathrm{C}$.

Моделювання проводилось у програмі THERM.

\section{Результати}

Згідно з ДБН В.2.6-31:2016 «Теплова ізоляція будівель» у приміщеннях 3 нормальним вологісним режимом при температурі нижче $+12{ }^{0} \mathrm{C}$ вологість повітря повинна знаходитись у межах $60 \% \leq \phi \leq 75 \%$. При температурі повітря $+10^{\circ} \mathrm{C}$ температура Тр точки роси буде знаходитись в межах $+2,6^{\circ} \mathrm{C} \ldots+5,8^{\circ} \mathrm{C}$.

\section{Таблиця 1}

Температура зовнішньої та внутрішньої поверхонь стін підвалу

\begin{tabular}{|c|c|c|c|c|c|c|}
\hline \multirow{2}{*}{$\begin{array}{c}\text { Точки } \\
\text { заміру }\end{array}$} & \multicolumn{2}{|c|}{ Зразок 1 } & \multicolumn{2}{c|}{ Зразок 2 } & \multicolumn{2}{c|}{ Зразок 3 } \\
\cline { 2 - 7 } & початок & кінець & початок & кінець & початок & кінець \\
\hline 1 & 5,2 & 10,2 & 4,5 & 9,9 & 5,5 & 10,3 \\
\hline 2 & 5,2 & 8,7 & 2,0 & 8,0 & 6,4 & 9,0 \\
\hline 3 & 6,0 & 8,8 & 3,0 & 8,2 & 6,7 & 9,0 \\
\hline 4 & 8,1 & 9,3 & 8,0 & 9,2 & 8,3 & 9,4 \\
\hline 5 & 9,0 & 9,6 & 9,0 & 9,6 & 9,1 & 9,6 \\
\hline
\end{tabular}



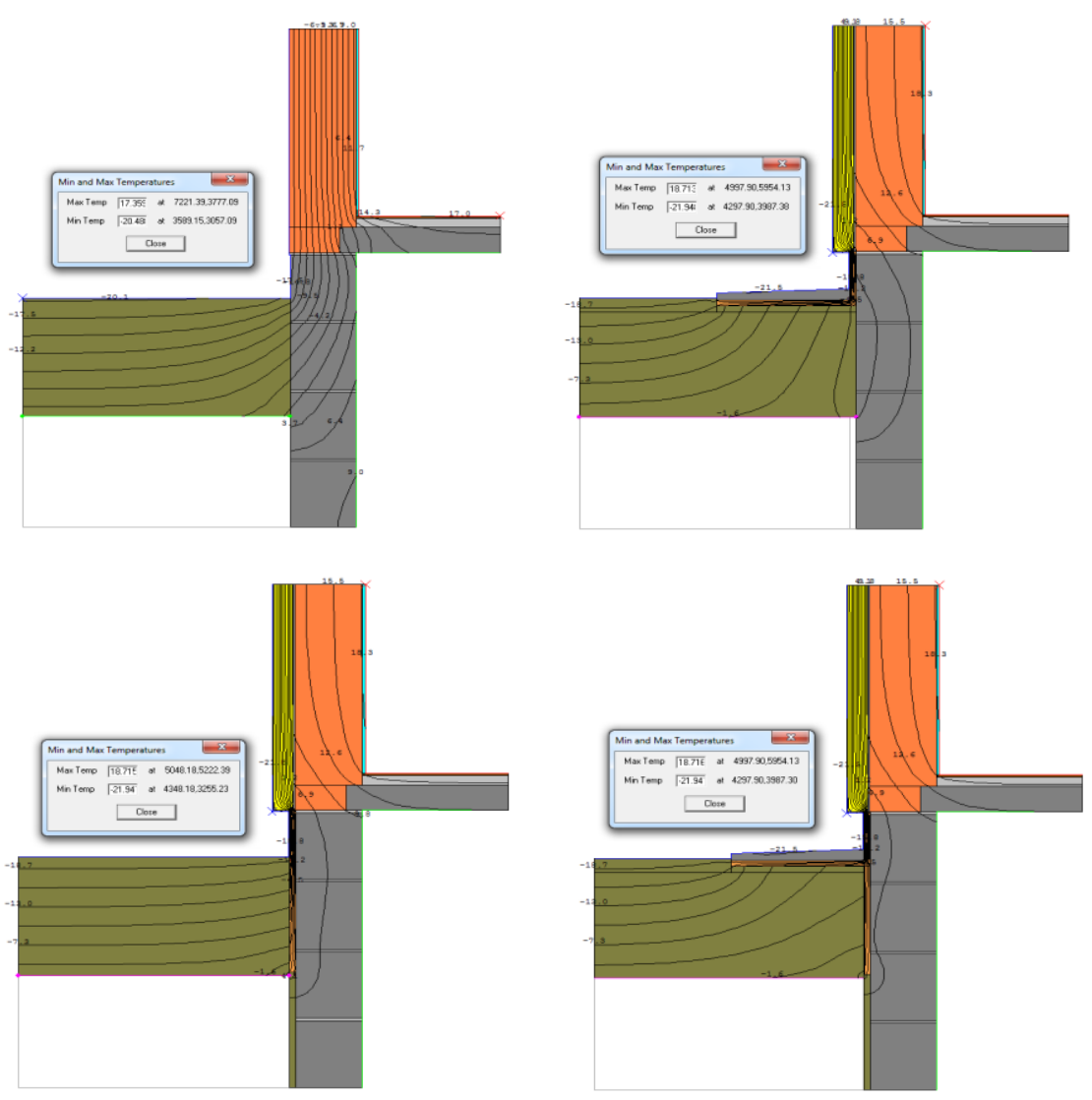

Рис. 1. Температурні ізолініі 


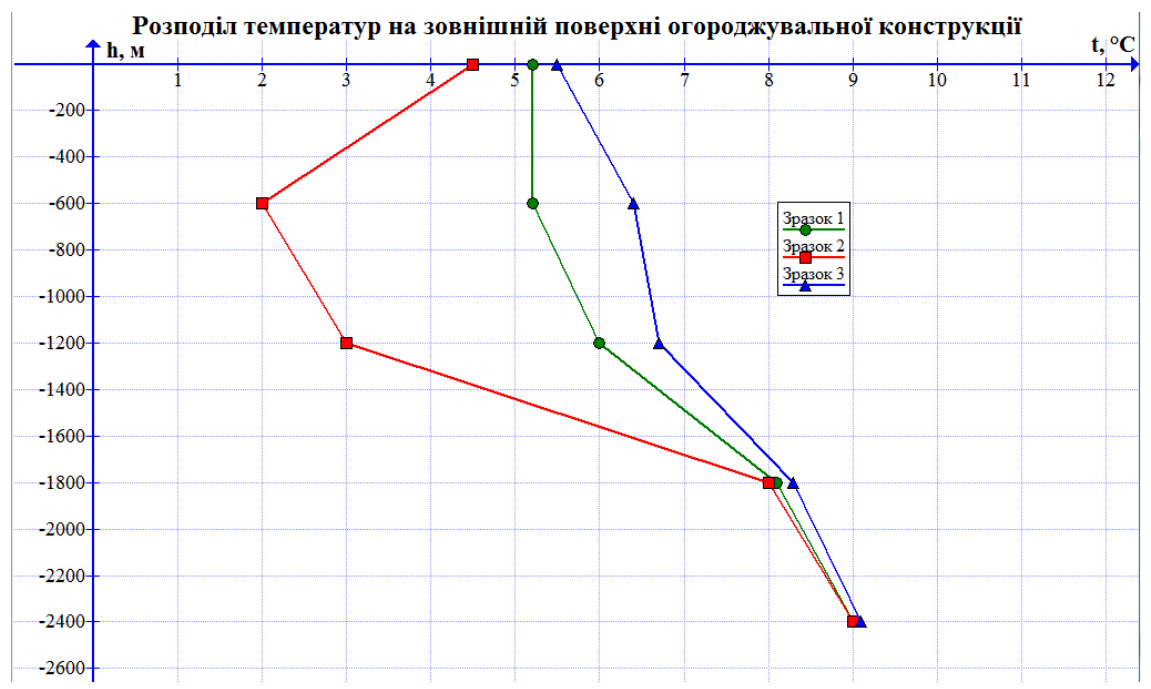

Рис. 2. Розподіл температур по зовнішній поверхні стіни

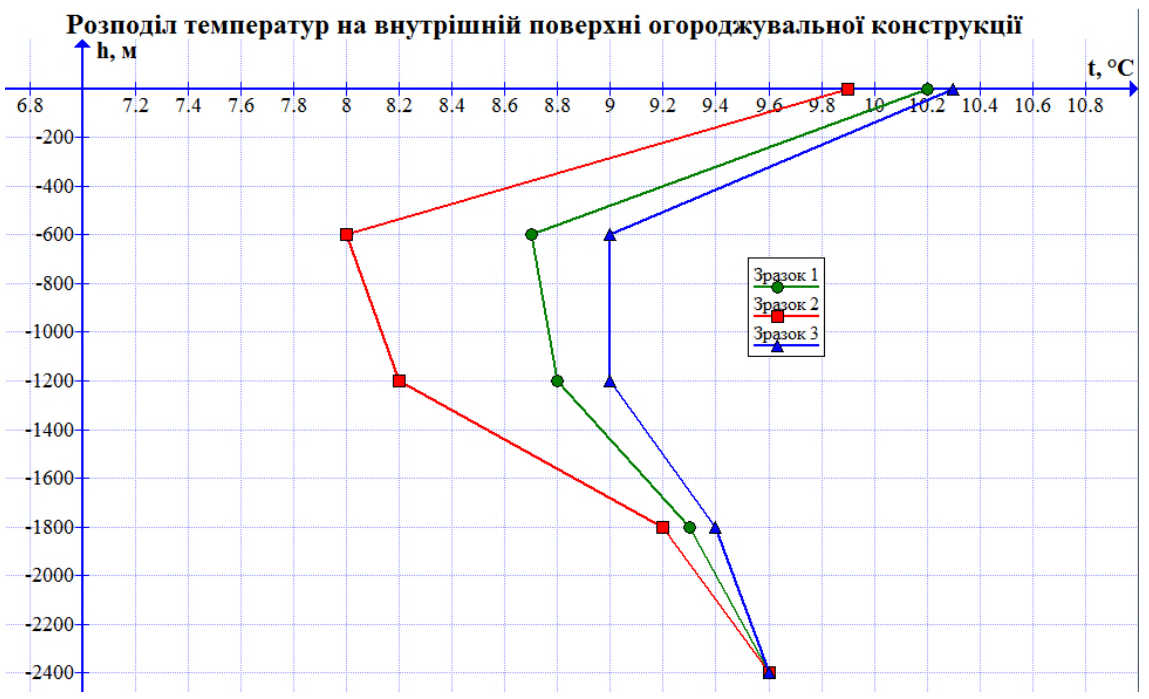

Рис. 3. Розподіл температур по внутрішній поверхні стіни 


\section{Висновки}

1. Температура по внутрішній поверхні стіни підвалу у всіх трьох зразках не виходила за допустимі межі $\left(+2,6^{0} \mathrm{C}\right.$ $\left.\ldots+5,8^{0} \mathrm{C}\right)$.

2. Мінімальне значення температури спостерігалось у зразку №2 і складало $8,0{ }^{\circ} \mathrm{C}$.

3. Номінально схеми усіх зразків можна застосовувати при виконанні робіт з утеплення стін підвалу.

4. Зразок №1, який повністю відповідає вимогам ДБН В.2.631:2016 «Теплова ізоляція будівель» та ДСТУ Б В.2.6189:2013 «Методи вибору теплоізоляційного матеріалу для утеплення будівель» показав цілком нормальну та адекватну роботу. Єдиним недоліком $є$ значна трудомісткість при виконанні таких робіт в ході термомодернізації, а також необхідність проводити обстеження міцності конструкцій стіни перед розкривними роботами.

5. Зразок №2 забезпечує нормальну роботу системи утеплення, однак його показники на глибині до $-1,6$ м $є$ значно гіршими. Основною його перевагою $є$ низька вартість та трудомісткість робіт.

6. Зразок №3 Об’єднав у собі переваги та недоліки зразків №№ 1 і 2 та показав найкращі результати.

\section{Список використаних джерел}

1. Програма енергозбереження (підвищення енергоефективності) Київської області на 2017 - 2020 роки. [Електронний ресурс] - Режим доступу: koda.gov.ua/wp-content/uploads/2017/05/216_2017.doc

2. Енергоефективність у житловому секторі: сьогодення і майбутнє [Електронний ресурс] - Режим доступу:

https://topkonotop.com/publication/energoefektivnist-u-zhitlovomu-sektorisogodennya-i-majbutny

3. Закон України від 22 червня 2017 року № 2118-VIII "Про енергетичну ефективність будівель". Статус: набув чинності 23.07.2017 року, вводиться в дію 23.07.2018 року. [Електронний ресурс]. - Режим доступу: http://zakon3.rada.gov.ua/laws/show/2118-19.

4. Петрусь В. В. Оцінка енергоощадності багатоквартирних будинків м. Вінниці // Електронне наукове видання матеріалів конференції, м. Вінниця, 2017. - Режим доступу: https://conferences.vntu.edu.ua/index.php/allfbtegp/all-fbtegp-2017/paper/view/1616/2460 